\title{
ANNOUNCEMENTS
}

FRANÇOIS PRIZE 1981

In 1974, with a view to stimulating the study of international law and private international law, the Netherlands International Law Association created the François Prize, amounting to Dfl. 1,500.

This prize is awarded for an essay, an article in a periodical, or other written work in the fields of international law or private international law.

Undergraduates in the law faculties of the universities in the Netherlands who are under 30 years of age and have written their entry prior to receiving their degree may compete for this prize.

In reaching its decision, the jury will consider, among other things, originality, command of the subject-matter, and linguistic usage. Entries should be submitted, preferably in triplicate, before 1 January 1981 to the Secretariat, c/o Javastraat 2C, The Hague.

\section{SYMPOSION ON INTERNATIONAL ENVIRONMENTAL LAW}

Under the auspices of the Stichting Reinwater, the Department of Administrative Law and the Department of Private International Law \& Comparative Law of the University of Amsterdam will organize on Thursday and Friday 11 th and 12th June 1981 a symposion on international environmental law in the Free University, Amsterdam.

The subject of the symposion will be the interaction of administrative law and transnational environmental pollution. Special attention will be given to the deterioration of the natural environment as a result of surface water pollution, air pollution, nuclear radiation, or noise, as far as their sources and effects are situated in different countries.

The symposion purports to gather information on the extent to which these transnational fenomena are covered by the domestic and international law in force in the 
participating countries (Belgium, France, German Federal Republic, The Netherlands and Switzerland).

The discussions will be based on reports submitted by experts from all participating countries covering the present situation in their respective countries and probable future developments (Belgium: Prof. Dr. L.P. Suetens, University of Louvain; France: Prof. Dr. A. Ch. Kiss, University of Strasbourg, President of the European Council on Environmental Law; German: Dr. Alfred Rest, University of Cologne; Netherlands: Mr. K. Langelaar, lawyer; Switzerland: Prof. Dr. Th. Fleiner Gerster, University of Fribourg).

Furthermore, a number of actual situations will be discussed to exemplify the problems in litigation on transnational pollution. The reports and case studies will be mailed to participants in advance of the symposion.

The symposion aims to draft recommendations on the direction the domestic and international law of the participating countries should take. After the symposion a book containing the recommendations, reports and other documents will be published.

The symposion papers will be written either in English or in French. During the symposion the discussions will be simultaneously translated into English, French and Dutch.

Anyone interested in the subject matter is welcome to participate. Registration is Dfl. $125,--$. Included are symposionpapers, luncheons, coffee, tea etc. The symposion is sponsored by the Dutch Ministry of Public Health and Environmental Affairs.

Further information and registration forms are available at the Stichting Reinwater, Damrak 37, 1012 LK Amsterdam. 